\title{
ZABLUDOV GOSPEL OF 1569: \\ THE FIRST PRINTED BOOK OF IVAN FYODOROV AND PYOTR MSTISLAVETS IN PODLYASHIE ${ }^{1}$
}

\section{Abstract:}

The article tracks the history of the publication and study of one of the most famous Slavic old printed books, the Zabludov's Gospel of 1569.

\section{Keywords:}

Zabldov's Gospel, didactic Gospels, Ivan Fyodorov, Pyotr Mstislavets, Church Slavonic language.

АННОТАЦИЯ: Л.Л. ЩАВИНСКАЯ. «ЗАБЛУДОВСКОЕ ЕВАНГЕЛИЕ 1569 Г.: ПЕРВАЯ ПЕЧАТНАЯ КНИГА ИВАНА ФЕДОРОВА И ПЕТРА МСТИСЛАВЦА НА ПОДЛЯШЬЕ».

В статье представлена история издания и изучения одного из самых известных в истории славянской старопечатной книжности - Заблудовского Евангелия 1569 г.

\section{Ключевые слова:}

Заблудовское Евангелие, учительные евангелия, Иван Федоров, Петр Тимофеев Мстиславец, церковнославянский язык.

7 abludov Gospel is one of the most famous publications in the history of Slavic incunabula. It was printed in Podlyashie, in Zabludov, on the estate of the Khodkevich magnates, who founded the Monastery of the Annunciation in Suprasl. One of the oldest Orthodox publishing houses was established there in the mid-1560s, housing the first typographers from Moscow: Ivan Fyodorov Moskvitin and Pyotr Timofeev Mstislavets. On 8 July 1568 their first book, the Didactic Gospel began to be printed at the Zabludov printing house. The typesetting was done using fonts brought by the typographers from Moscow. The headpieces, endings and initial letters used in this work, were used by Ivan Fyodorov and Pyotr Mstislavets when publishing the first dated book of the Moscow press: the Moscow Apostle of 1564. The printing of the Didactic Gospel was completed on 17 March 1569. On its title page it states: "The Book called the Didactic Gospels. Selected from all four Evangelists. And from many Holy Scriptures. And is given to God's church to be read every week. And also on the Lord's holidays and the holidays of other saints. To instruct Christian people in spiritual and physical improvement. Printed with the help of God."

\footnotetext{
1 The work was carried out with the financial support of the RFBR (grant № 18-512-76004).
} 
The publication was a collection of sermons and teachings on gospel readings arranged for various weeks and holidays. There were two main varieties of teaching gospels. The more ancient of them, which is a literal translation from Greek abbreviations of "paternal interpretations," is associated in the manuscript tradition with the name of Constantine of Preslav, a Bulgarian bishop and disciple of the first Slavic teacher St Methodius. This gospel contains 51 conversations for Sunday readings. The second version of the Didactic Gospel, which appeared much later than the first, was published in Zabludov. It is often called the Patriarchal homily of Constantinople, which was supposedly composed by several authors who lived in the 12th, 13 th and even the 14 th centuries. The composition of said teaching gospel is significantly different from the first and has two parts: 53 or 52 teachings for Sundays and some other days, and 26-25 teachings on fixed holidays and the corresponding weeks from 1 September to 29 August.

The Slavic translation of this collection from Greek appeared relatively quickly

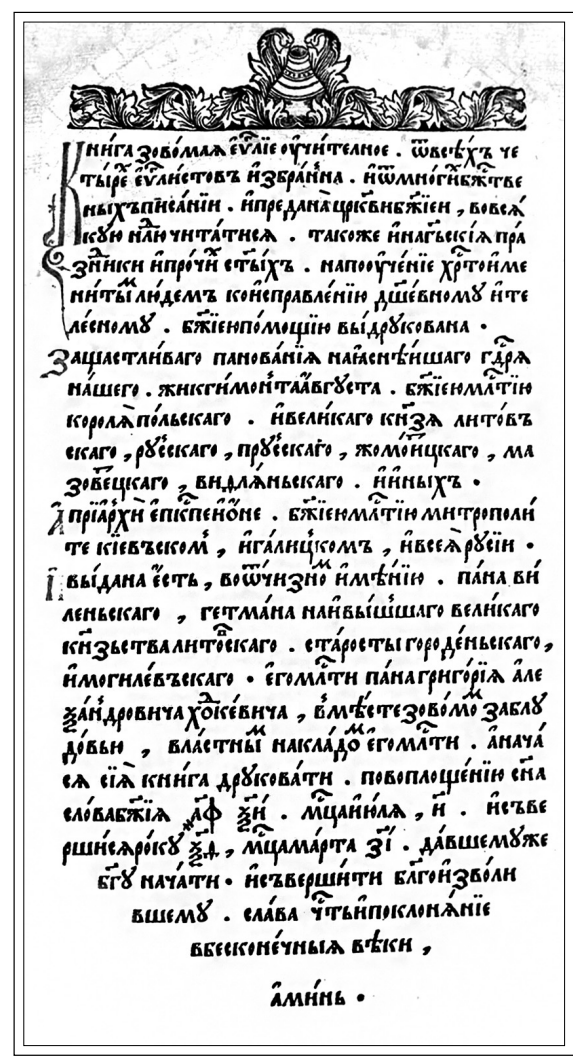

The output sheet of the Zabludov Gospel, 1569 after its creation. The exact date of the translation is unknown, but according to scholars, it originated in the late 14 th to 15 th centuries. The basis for the printing of Didactic Gospel was one of the earliest copies of the Slavic translation. A collection of copies of this book, then distributed in Podlyashie, is the likely source of this gospel. We managed to find an ancient copy of the Didactic Gospel from Podlyashie, which is probably the prototype of the Zabludov publication. It comes from the library of the Suprasl monastery.

The book was not translated into "simple speech" but printed directly from the ancient manuscript, because the publishers believed that the modern translation of ancient "true" books distorted their meaning, and that the "Gospel is educational"; in their opinion, even without translation the book was "easy and useful for reading." Nevertheless, before setting the type, the text of the collection was thoroughly edited. The book opens with a foreword by the tycoon Gregory Khodkevich: "That is why I, Gregory Alexandrovich Khodkevich, having seen the Christian teaching in this book, wished God's word to multiply, and the teaching of the Greek law to people to spread, because there is a lack of these 
books in various places. And I did not spare any treasures given me by God in this undertaking. In addition, I also found for myself two men learned in printing: Ivan Fyodorovich Moskvitin and Pyotr Timofeevich Mstislavets. I commanded them to found the printing house and to print this Didactic Gospel."

The publication is provided with an extensive table of contents: "The chapters which are contained in this book." The book also contains the "Word on the Ascension," which was written by St Cyril of Turov, a well-known East Slavic preacher. It was included in all three subsequent reprints of the Zabludov Didactic Gospel carried out in the Grand Duchy of Lithuania in the 16th century.

The Zabludov Didactic Gospel of 1569 had its own special fate. It had a significant impact on the Orthodox both within the Grand Duchy of Lithuania and far beyond its borders, including the Muscovite state and the Balkans. It was repeatedly reprinted, used for work on other publications, copied in different countries, translated into other languages. An example is the Bulgarian manuscript codex of the beginning of the 17 th century made in Târnovo by Hieromonk Daniil and now stored in the collection of the Bulgarian National Library of Sts Cyril and Methodius. It is one of the first Bulgarian manuscript books based on East Slavic printed texts.

About ten years after the publication of the Didactic Gospel in Zabludov, it was reprinted in an anonymous Orthodox printing house in Vilna. Another reprint of it in the same city was carried out in 1595 in the Mamonich Printing House, belonging to an Orthodox family of Belarusian merchants. Sometime later this book was again reprinted there.

About 50 copies of the Zabludov $D i$ dactic Gospel of 1569 have survived to this day. This voluminous collection of more than 800 pages, a huge book, is now preserved in many countries on different continents. Numerous records of the surviving copies testify to the unusually wide distribution of the book throughout the Orthodox world. Quite quickly, the $D i$ dactic Gospel from Zabludov reached the Bulgarians, Russians, Serbs, and other Orthodox peoples, spread to the territory of the Grand Duchy of Lithuania and the Kingdom of Poland, primarily in the Ukrainian lands and Lemkovshchyna.

Translated by Igor Kaliganov

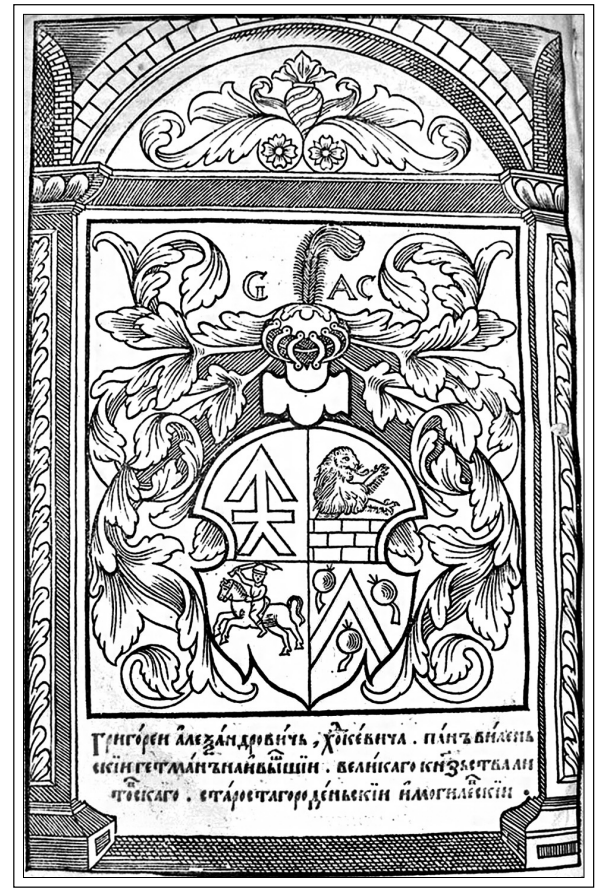

The Coat of arms of G.A. Khodkevich. Zabludov Gospel of 1569 


\section{BIBLIOGRAPHY}

Maslov S.I. Kirill Trankvillion-Stavroveckij i ego literaturna dejatel'nost'. Kiev, 1984. Nemirovskij E.L. Ivan Fedorov v Belorussii. Moskva, 1979.

Łabyncew., Szczawińska Ł.W mieście zwanym Zabłudowem. Białystok, 1995.

\section{ILLUSTRATIONS}

1. The output sheet of the Zabludov Gospel, 1569.

2. The Coat of arms of G.A. Khodkevich. Zabludov Gospel of 1569.

3. The first page of the Preface by G.A. Khodkevich in the Zabludov Gospel of 1569.

4. Foreword by Ivan Fyodorov and Pyotr Mstislavets in the Zabludov Gospel of 1569.

5. "The word of Ascension" by St Cyril of Turov in the Zabludov Gospel of 1569.

6. First sheet of contents in the Zabludov Gospel of 1569.

7. A portrait of G.A. Khodkevich.

8. View of Suprasl's Annunciation monastery. Engraving from the 19 th century.

9. Record of widow of G.A. Khodkevich in the Zabludov Gospel of 1569.

10. Modern view of the Annunciation monastery in Suprasl. 